\title{
Forest Diversity and Modeling Diameter Distribution of the Tropical Dryforest in East Nusa Tenggara, Indonesia
}

\author{
Almulqu, A. Ahmad* \\ Forestry Department, Kupang State Polytechnic of Agricultural, East Nusa Tenggara Province, Indonesia \\ *Corresponding author's E-mail address: ahmadalmulqu@yahoo.com
}

\begin{abstract}
The variation of forest conditions shows structural differences, species composition, and potential value as well as stand density. The need and important role of stand structure model in forest management, particularly in forest-based product regulation become the supply demands quantitatively for various forest conditions in Indonesia. The objective of the study was to determine the stand structure model of dry forest. The study was conducted at the dry forest of Binafun, Bonmuti, Letkole and Oelbanu, East Nusa Tenggara Province. Determination of the best stand structure model based on maximum likelihood function of family distribution that tested including the function of exponential, gamma, lognormal and Weibull. A total of 2097 tree individuals, its representing 94 species, 72 genera and 45 families, were found in the research sites. Eucalyptus urophylla were found to be the most dominant species in the research sites and Elattostachys verrucosa have potential to replace Dryobalanops aromatic. Most of family distribution models can describe the stand structure in research sites. The models presented here are the basis for further developments toward the tree diversity for general purpose in tropical dry forest management of East Nusa Tenggara, Indonesia.
\end{abstract}

Keywords — forest structural, species composition, stand density, stand structure model 


\section{INTRODUCTION}

The conditions of dry forest show specific in structure, species composition and potential value, as well as variation in stand density, and death and growth rate (Lewis, 2004). The diversity level of a vegetation is the result of a dynamic ecophysiological process and correlation with the local climatic condition, nutrient condition, tolerance range, biogeographic factors or the distribution of types and variations in the ecological condition of the forest (Lee 2002). Prodan (1968) states that the biometric characteristic of forest is a quantitative approach to explain the important processes in the forest, which studied the properties or characteristics of forest stands in size (metric) of a specific biological dimension as an identity which is quantitative (in ratio and interval scale). Most of the early researches in forest biometrics particularly in forest growth modeling is mainly aimed at plantations or forests, which do not have complexity as in tropical forests (Vanclay, 2003).

To explain the behavior of these variables can be used of modeling the distribution. Modeling of frequency distribution parameters such as diameter in various branches of forests science such as silvics, forestry and forest biometrics, is considered by scientists (Bahnemiry et al, 2013). For many years there were various activity and interest in describing the frequency distribution of diameter measurements in forest stands using probability density functions (Khongor et al, 2011). Diameter distribution modelling has been an intrinsic part of forest management planning and research in the recent times. This has often been used in bridging the gap between crude stand-level simplification and complex individual tree models (Thomas and Cao, 2006).

They are used to value forests, plan harvest activities, predict forest growth, and thus enhance forest productivity (Burkhart and Tome', 2012). Size distributions can also be used to infer past disturbance events, forest successional status, and aboveground biomass stocks (Coomes and Allen 2007). When assessed at the species level, they can be used to provide information on species regeneration strategies, demographic rates, and population trends (Knight 1975).

The objective of this research were obtaining importance value index (IVI), basal area, Shannon diversity index and model of stand structure of dry forest in East Nusa Tenggara province. This quantitative models can be used to improve the accuracy and validity of the projected regulation in achieving a sustainable dryforest management in East Nusa Tenggara, Indonesia.

\section{MATERIALS AND METHODS}

\section{Research Areas}

Study plot was selected in the East Nusa Tenggara province, Indonesia, located at S 09039'12 9.22', and $\mathrm{E} 124^{\circ} 01^{\prime} 421.16^{\prime}$ " for Binafun dry forest, $\mathrm{S}$ 09037'46.50', and E 1240127.92'" for Bonmuti dry forest, S $09^{0} 41^{\prime} 02.62^{\prime}$ ' and E $123^{\circ} 48^{\prime}$ for Letkole dry forest, $\mathrm{S} 09^{\circ} 42$ '28.59' ' and E $123^{\circ} 53^{\prime} 04.82$ ' ' for Oelbanu dry forest with altitudinal elevation 125$636 \mathrm{~m}$ above sea level (Figure 1). Until today, in the research sites, there was no information on the modeling of tree diameter distribution.



Figure 1. Map of research sites

The climate of East Nusa Tenggara province (NTT) is untypically dry relative to the rest of Indonesian archipelago. Of $4.6 \times 10^{6}$ ha land area of the province, $1.0 \times 10^{6}$ ha receives annual rainfall
$(<1,000 \mathrm{~mm})$, and $3.3 \times 10^{6}$ ha receives annual rainfall $(1,000-2,000 \mathrm{~mm})$ with more than 6 dry months (<100 mm monthly rainfall) and <4 wet months (>200 mm monthly rainfall) (Balitklimat, 
2004). With the short duration of wet months, rainfall tends to be very high (200-500 $\mathrm{mm}$ monthly rainfall) during the wet months and so is rainfall intensity. About $71 \%$ area are hilly (15-30\% slope) to mountainous (>30\% slope).

The high-intensity rainfall during the rainy season and steep slope topography cause high soil erosion. The long-term impact of erosion process can be observed from the shallow $(<50 \mathrm{~cm})$ soil depth at the interfluves, the upper and middle slopes positions, and deep (sometimes reaching more than
$1 \mathrm{~m}$ ) soil depth at the valley bottom (Mulyani et al, 2013).

\section{Plant Census}

A 8-ha permanent sampling plot was set up within the nature for the survey of the dry forest. A design of research plots is a permanent plot, with a plot size of $100 \times 100 \mathrm{~m}$ and was divided into 16 subplots with a size of $25 \times 25 \mathrm{~m}$ (Figure 2). The data collection is based on the stands inventory by census in research plots. All individual trees $\geq 5 \mathrm{~cm}$ diameter at breast height (DBH) were tallied, tagged, and recorded by species name and DBH.

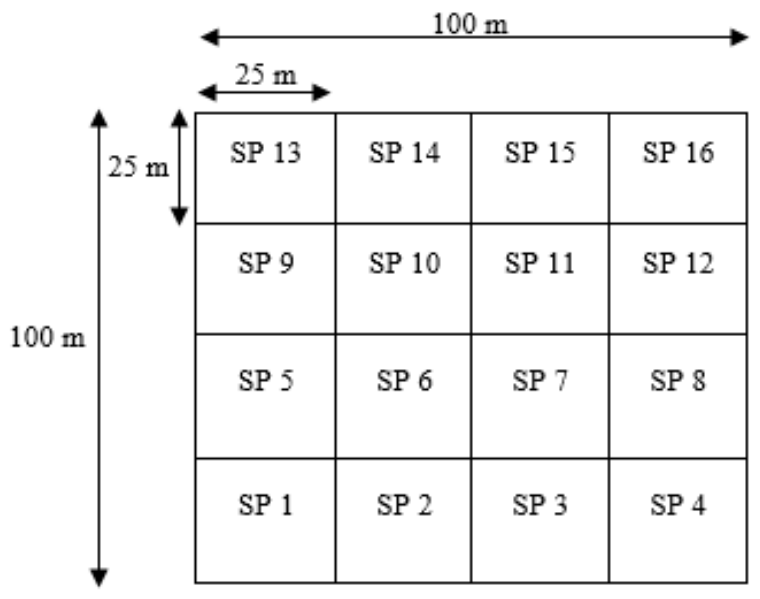

Figure 2. Design of sample plots

Determination of Importance Value Index (IVI)

According to Soerianegara and Indrawan (1988), species importance value index (IVI) for a species is a composite of three ecological parameters density, frequency and basal area, which measure different features and characteristics of a species in its habitat. Ecologically, density and frequency of a species measure the distribution of a species within the population while basal area measures the area occupied by the stems of trees.

IVI was used for the assessment of the distribution of species abundance which is calculated in the following formula:

IVI = relative frequency + relative density + relative dominance

Determination of Basal Area and Shannon

Diversity Index

Basal area per tree is the cross-sectional area of a tree at breast height. It can be calculated from diameter at breast height (Kusmana, 1997).

$\mathrm{BA}=1 / 4 \pi \cdot \mathrm{d}^{2}$

Where,

$\mathrm{BA}=$ basal area $\left(\mathrm{m}^{2}\right)$

$\pi=$ constant 3.142 $\mathrm{d}=$ diameter at breast height of a tree $(\mathrm{m})$

Species diversity will be computed using Shannon's and Simpson's diversity indices (Magurran, 1987). The Shannon diversity index computed as $\mathrm{H}^{\prime}=\sum_{\mathrm{i}=1}^{\mathrm{s}}\left(\frac{\mathrm{ni}}{\mathrm{N}}\right) \ln \left(\frac{\mathrm{ni}}{\mathrm{N}}\right)$,

Where,

$\mathrm{N}=$ number species

$\mathrm{ni}=$ number of individuals in a species in sample quadrats

\section{Determination of Family Model}

The models are included in this selection is exponential distribution family, gamma, lognormal and Weibull models. The determination of the best model based on the maximum likelihood function (Suhendang, 1985). The equation of models are as follows:

Exponential distribution family model

1). Density function 


$$
\mathrm{f}(\mathrm{x})=\left(\frac{1}{\theta}\right) \exp ^{-}\left(\frac{\mathrm{x}}{\theta}\right)_{\mathrm{I}(0, \sim)(\mathrm{x})}
$$

2). Prediction of $\theta$ parameter

$\hat{\theta}=\left(\frac{1}{\mathrm{n}}\right) \sum_{\mathrm{i}=1}^{\mathrm{n}} \mathrm{X}_{\mathrm{i}}=\overline{\mathrm{X}}$

\section{3). Maximum likelihood function}

$$
\log \mathrm{L}=-\mathrm{n} \log (\mathrm{e} \theta)
$$

where $\theta$ is the continuous inverse scale parameter

Gamma model

1). Density function:

$$
f(x)=\frac{x^{\alpha-1} \exp \left(\frac{-x}{\beta}\right)}{\beta^{\alpha} \Gamma(\alpha)} I_{(0, \sim)(x)}
$$

2). Prediction $\alpha, \beta$ of parameter :

$$
\hat{\alpha}=\left\{\begin{array}{l}
\left(\frac{1}{\mathrm{Y}}\right)\left(0.5000876+0.164885 \mathrm{Y}-0.0544274 \mathrm{Y}^{2}\right) ; \\
0<\mathrm{Y} \leq 0.5772 \\
\left(\frac{1}{\mathrm{Y}}\right)\left(17.79728+11.968477 \mathrm{Y}+\mathrm{Y}^{2}\right)^{-1} \\
\left(8.898919+9.05995 \mathrm{Y}+0.9775373 \mathrm{Y}^{2}\right) \\
; 0.5772<\mathrm{Y} \leq 17
\end{array}\right.
$$

Where;

$$
\begin{aligned}
& Y=\ln \left[\frac{\sum_{i=1}^{n} \frac{x_{i}}{n}}{\left[\sum_{i=1}^{n} x_{i}\right]^{1 / n}}\right] \\
& \hat{\beta}=\frac{x}{\wedge}
\end{aligned}
$$$$
\alpha
$$

3). Maximum likelihood function:

$$
\begin{aligned}
& \log \mathrm{L}=-\operatorname{nlog}\left(\beta^{\alpha} \Gamma(\alpha)\right)+ \\
& (\alpha-1) \sum_{\mathrm{i}=1}^{\mathrm{n}} \log \mathrm{x}_{\mathrm{i}}-\sum_{\mathrm{i}=1}^{\mathrm{n}} \mathrm{x}_{\mathrm{i}} / \beta(\log \mathrm{e})
\end{aligned}
$$

Where $\alpha$ is the continuous shape parameter and $\beta$ is the continuous scale parameter

Lognormal model

1). Density function:

$$
\mathrm{f}(\mathrm{x})=(1 /(\mathrm{x} \delta \sqrt{2 \pi})) \exp \left[-1 / 2\left(\frac{\ln \mathrm{x}-\mu}{\delta}\right)^{2}\right] \mathrm{I}
$$

2). Prediction $\alpha, \beta$ of parameter :

$$
\hat{\mu}=\left(\frac{1}{n}\right) \sum_{i=1}^{n} \ln x_{i}
$$

$$
\hat{\delta}=\left[\left(\frac{1}{n}\right) \sum_{i=1}^{n}\left(\ln x_{i}-\mu\right)^{2}\right]^{1 / 2}
$$

3). Maximum likelihood function:

$$
\begin{aligned}
& \log L=-n \log [\delta \sqrt{2 \pi}] \\
& -\sum_{i=1}^{n} \log x_{i}-\frac{1}{2} \sum_{i=1}^{n}\left(\frac{\ln x_{i}-\mu}{\delta}\right) \operatorname{loge}
\end{aligned}
$$

Where $\delta$ and $\mu$ are the continuous parameters

Weibull model

1). Density function:

$$
\mathrm{f}(\mathrm{x})=\left(\frac{\gamma}{\alpha}\right)\left(\frac{\mathrm{x}}{\alpha}\right)^{\gamma-1} \exp ^{-}\left|\left(\frac{\mathrm{x}}{\alpha}\right)^{\gamma}\right| \mathrm{I}_{(0, \sim)(\mathrm{x})}(13)
$$

2). Prediction of $\mu, \gamma$ of parameter point:

$$
\begin{aligned}
& \hat{\mu}=\left[1 / n \sum_{i=1}^{n} x_{i}^{\gamma}\right]^{(1 / \gamma)} \\
& \hat{\gamma}=\left[\left(\sum_{i=1}^{n} x_{i} \ln x_{i}\right)\left(\sum_{i=1}^{n} x_{i}\right)-(1 / n) \sum_{i=1}^{n} \ln x_{i}\right]
\end{aligned}
$$

3). Maximum likelihood function:

$\log \mathrm{L}=n \log (\gamma \log +(\gamma-1)$

$\log \sum_{\mathrm{i}=1}^{\mathrm{n}} \mathrm{x}_{\mathrm{i}}-\mathrm{n}(\gamma-1) \log \alpha-\left(\alpha / \gamma \sum_{\mathrm{i}=1}^{\mathrm{n}} \mathrm{x}_{\mathrm{i}}\right) \log \mathrm{e}$

Where $\gamma$ and $\alpha$ are the continuous shape parameter Statistical Analysis

Once the expected values have been computed, the chi-square test statistic is computed as (Simon, 2007):

$$
\mathrm{X}^{2} \mathrm{cal}=\sum \frac{\hat{\mathrm{y}_{\mathrm{i}}-\mathrm{y}^{2} \mathrm{i}}}{\mathrm{y}_{\mathrm{i}}}
$$

Where:

$\mathrm{X}^{2} \mathrm{cal}=$ value of chi square test

$\mathrm{y}^{2}{ }_{\mathrm{i}}=$ numbers of vegetation (observed) on diameter to- $\mathrm{i}, \mathrm{i}=1,2, \ldots$.

$\hat{y}_{\mathrm{i}}=$ numbers of vegetation (model) on diameter to-i,i $=1,2, \ldots$.

Hypothesis test :

$\mathrm{H}_{0}: \mathrm{y}_{\mathrm{i}=\mathrm{y}_{\mathrm{i}}}$

$\mathrm{H}_{1}: \mathrm{y}_{\mathrm{i}} \neq \mathrm{y}_{\mathrm{i}}$

Test criteria:

$\mathrm{X}^{2} \mathrm{Cal}<\mathrm{X}^{2}$ Table $=\mathrm{H}_{0}$ accept

$\mathrm{X}^{2} \mathrm{Cal}>\mathrm{X}^{2} \mathrm{Table}=\mathrm{H}_{0}$ reject 


\section{RESULTS AND DISCUSSIONS}

Importance Value Index (IVI) Values

A total of 2097 tree individuals, representing 94 species, 72 genera and 45 families, were identified within the 8.0 ha area survey. The species are found in complete growth stage (seedling, sapling, pole and tree) among the research sites are Aglaia heptandra (Letkolea), Alstonia villosa (Binafun), Casuarina junghuhniana (Noebesi), Celtis wightii (Bonmuti), Ceriops tagal (Binafun), Dryobalanops aromatica (Noebesi), Dysoxylum gaudichaudianum (Binafun and Letkole), Eucalyptus urophylla (Bonmuti and Noebesi), Eugenia littorale (Bonmuti), Euodia macrophylla (Bonmuti), Ficus ampelos (Letkole), Ficus nervosa (Binafun), Ficus variegata (Bonmuti), Lagerstroemia sp (Bonmuti),

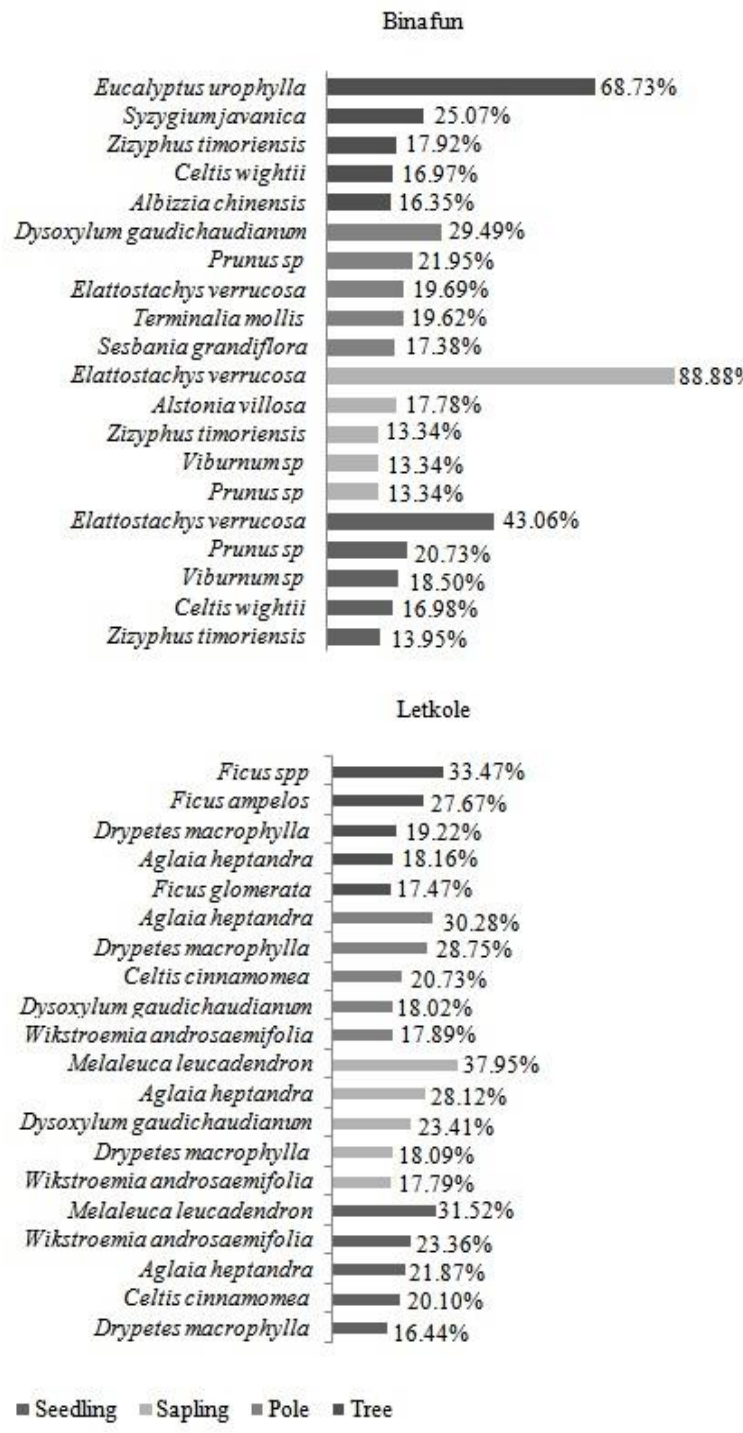

Melaleuca cajuputi (Letkole), Phaleria laurifolia (Binafun and Bonmuti), Polyscias rumphiana (Binafun), Tarenna pubiflora (Letkole), Viburnum sp (Binafun), Wikstroemia androsaemifolia (Letkole), Zizyphus timoriensis (Binafun and Bonmuti) and Zizyphus timoriensis that can be found at all the research sites.

The highest IVI value was that of Elattostachys verrucosa (88.88 \%) followed by Eucalyptus urophylla (68.73\%) in Binafun and Ceriops tagal (113.88 \%) followed by Dryobalanops aromatica in Oelbanu. Based on IVI values, Eucalyptus urophylla were found to be the most dominant species in the study area (Table $\mathbf{2} \boldsymbol{\&}$ Table 3) and Elattostachys verrucosa have potential to replace Dryobalanops aromatica as dominant species in Binafun and Bonmuti (Figure 3).

Bonmuti
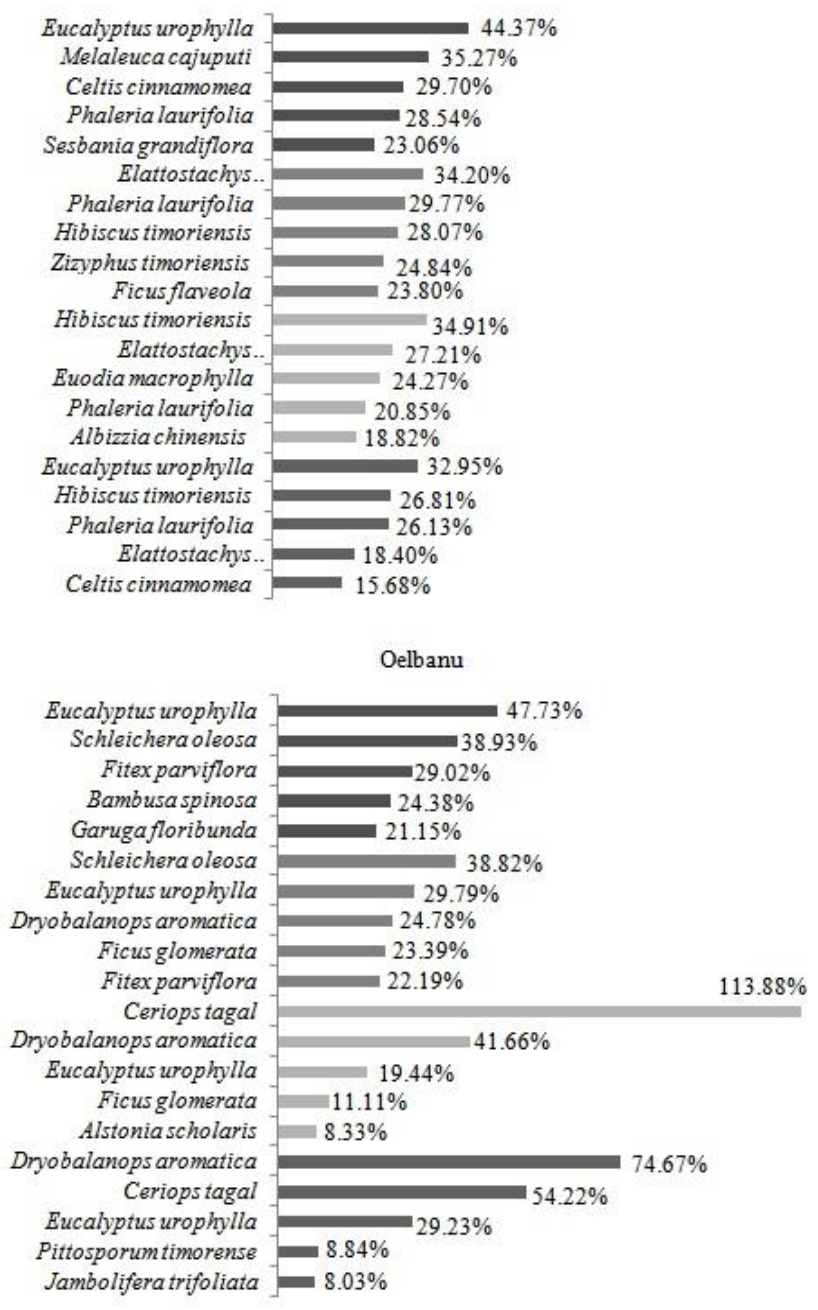

Figure 3. Five highest IVI for each research sites

Density, Basal Area and Shanon Index

The mean stand density was 353.62 individuals/ha. The highest stand density was observed in site 2 of Oelbanu (545 individuals/ha), whereas the lowest stand density was observed in site 1 of Oelbanu (166 individual/ha), and the other six plots showed moderate densities. The density of different tree species is along the study area. The 
basal area in all the study plots ranged from 5.78 $\mathrm{m}^{2} /$ ha (site 2 of Bonmuti) to $27.79 \mathrm{~m}^{2} /$ ha (site 1 of Binafun) and the mean basal area for the four plots was $19.97 \mathrm{~m}^{2} /$ ha. Comparison of Shannon-Wiener indices ( $\left.\mathrm{H}^{\prime}\right)$ between the eight sites indicate a no significant different was found in tree species, except for site 1 of Oelbanu (1.5 \pm 0.029$)$. Shannon index values for tree species diversity in this study ranged between $1.5 \pm 0.029$ and $3.9 \pm 0.004$ (Table 1), high value of Shannon index in this research relate to high tree species diversity and abundance in research sites and it was significantly influenced by forest structure and species composition (Huang et al 2003).

Table 2. The value of density, basal area and Shannon index

\begin{tabular}{|c|c|c|c|c|c|c|c|c|}
\hline \multirow{2}{*}{$\begin{array}{c}\text { Paramete } \\
\text { r }\end{array}$} & \multicolumn{2}{|c|}{ Binafun } & \multicolumn{2}{|c|}{ Bonmuti } & \multicolumn{2}{|c|}{ Letkole } & \multicolumn{2}{|c|}{ Oelbanu } \\
\hline & Site 1 & Site 2 & Site 1 & Site 2 & Site 1 & Site 2 & Site 1 & Site 2 \\
\hline $\begin{array}{l}\text { Species } \\
\text { richness }\end{array}$ & 23 & 31 & 14 & 21 & 51 & 49 & 7 & 27 \\
\hline $\begin{array}{l}\text { Density } \\
\text { (ind/ha) }\end{array}$ & 352 & 219 & 273 & 225 & 515 & 534 & 166 & 545 \\
\hline $\begin{array}{l}\text { Basal } \\
\text { area } \\
\left(\mathrm{m}^{2} / \mathrm{ha}\right)\end{array}$ & 27.79 & 27.27 & 18.81 & 5.78 & 18.27 & 24 & 18.49 & 19.37 \\
\hline $\begin{array}{l}\text { Shannon } \\
\text {-Wiener } \\
\text { index } \\
\left(\mathrm{H}^{\prime}\right)\end{array}$ & $\begin{array}{c}3.3 \pm 0.00 \\
8\end{array}$ & $\begin{array}{c}3.2 \pm 0.00 \\
6\end{array}$ & $\begin{array}{c}3.24 \pm 0.00 \\
9\end{array}$ & $\begin{array}{c}3.28 \pm 0.00 \\
9\end{array}$ & $\begin{array}{c}3.8 \pm 0.00 \\
5\end{array}$ & $\begin{array}{c}3.9 \pm 0.00 \\
4\end{array}$ & $\begin{array}{c}1.5 \pm 0.02 \\
9\end{array}$ & $\begin{array}{c}3.07 \pm 0.0 \\
1\end{array}$ \\
\hline
\end{tabular}

Knowing species diversity is a useful tool in plant ecology and forestry to compare the composition of different species. Tree species diversity in tropical forests differ greatly from location to location mainly due to variation in biogeography, habitat, and disturbance (Padalia et al 2004). Density and frequency distributions of trees contribute to the structure of forests. Most of the species had low frequency suggesting that most of them would be expected in typical species abundance distribution (Yam and Tripathi, 2016) and tree species diversity that influences the forests are climate, stand structure, species composition, and geomorphology. Forest stand structure is a key element in understanding forest ecosystems and also an important element of stand biodiversity (Ozcelik 2009).

Family Distribution Model

Table 3 shows the parameter values of the four distribution functions while Table 4 shows that the goodness of fit of the distributions were tested with Chi-Square.

Table 3. Prediction of distribution parameter point

\begin{tabular}{cccccccc}
\hline & \multicolumn{2}{c}{ Lognormal } & \multicolumn{2}{c}{ Weibull } & Exponential & \multicolumn{2}{c}{ Gamma } \\
\hline & $\mu$ & $\delta$ & $\alpha$ & $\gamma$ & lambda & $\mathrm{k}$ & $\beta$ \\
\hline Binafun & 3.029 & 0.869 & 1.167 & 31.322 & 0.033 & 1.468 & 20.533 \\
Bonmuti & 3.092 & 0.791 & 1.309 & 32.533 & 0.033 & 1.772 & 16.875 \\
Letkole & 3.410 & 0.600 & 1.704 & 40.441 & 0.028 & 3.093 & 11.602 \\
Oelbanu & 3.198 & 0.654 & 1.774 & 33.315 & 0.034 & 2.820 & 10.482 \\
\hline
\end{tabular}

In Binafun dryforest, We accept $\mathrm{H}_{0}$ because Xcal of all distribution model $<$ Chi square table. Statistically, there is no significant evidence at $\alpha=0.05$, it showed that the distribution of dryforest in Binafun is similar from the model data $(\mathrm{p}<$ 0.005).

In anothers sites, the $\mathrm{H}_{0}$ is rejected for lognormal (Letkole, Oelbanu), weibull (Bonmuti, Letkole), exponential (Letkole, Oelbanu) and gamma distribution (Bonmuti, Letkole and Oelbanu) with a probability of $99 \%$, and only lognormal (Bonmuti), weibull (Oelbanu) and exponential distribution (Bonmuti) is accepted. This implies the Binafun site were accepted for all distribution models, meaning the data followed the all distribution. It can be concluded that the lognormal family distribution, weibull, exponential, and gamma can describe and explaining the diameter distribution pattern of vegetation at Binafun dryforest. And the model of lognormal, weibull and exponential family distribution is the best in explaining diameter distribution model only for Bonmuti, Oelbanu and Bonmuti dryforest, respectively (Table 4). 
Table 4. Summary of $X^{2}$ calculate and goodness of fit of distribution functions

for research sites

\begin{tabular}{cccccc}
\hline & Lognormal & Weibull & Exponential & Gamma & Chi square tabel \\
\hline Binafun & 9.418 & 4.982 & 10.134 & 5.925 & 14.067 \\
Bonmuti & 9.256 & $* 14.662$ & 9.519 & $* 15.099$ & 12.592 \\
Letkole & $* 37.183$ & $* 58.938$ & $* 203.337$ & $* 37.627$ & 12.592 \\
Oelbanu & $* 43.990$ & 13.288 & $* 229.452$ & $* 16.332$ & 14.067 \\
\hline
\end{tabular}

Figure 4 shows that there are more trees in lower dbh class that is sufficient enough to replace trees in the upper dbh class in the future, its in accordance with the results of IVI analysis that some species (Elattostachys verrucosa) have potential to replace Dryobalanops aromatica (Figure 3). The implication of this is that the dry forests are still undergoing regeneration and recruitment, which are vital indicators of forest health and vigour.
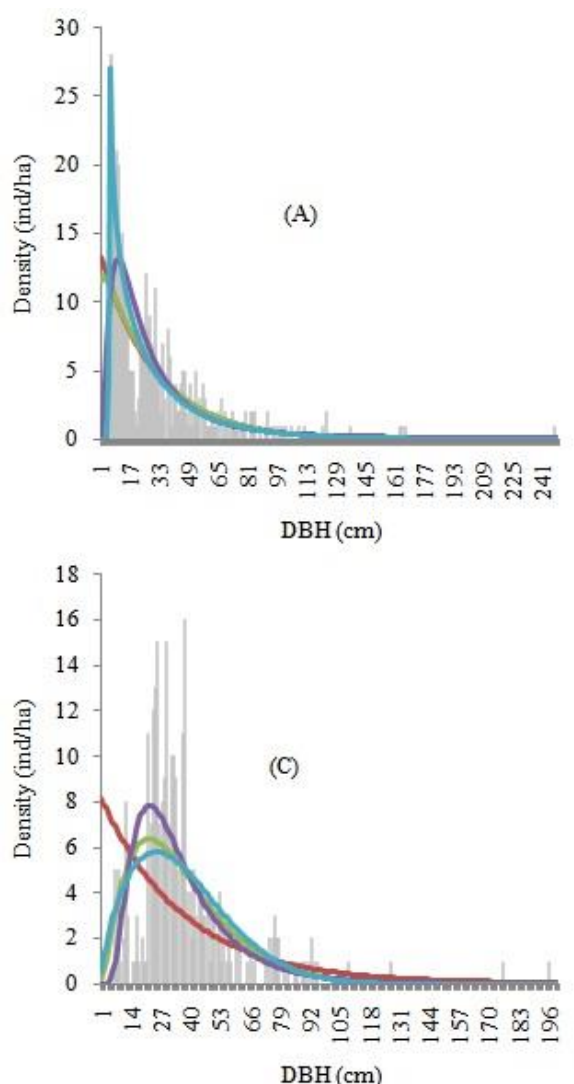
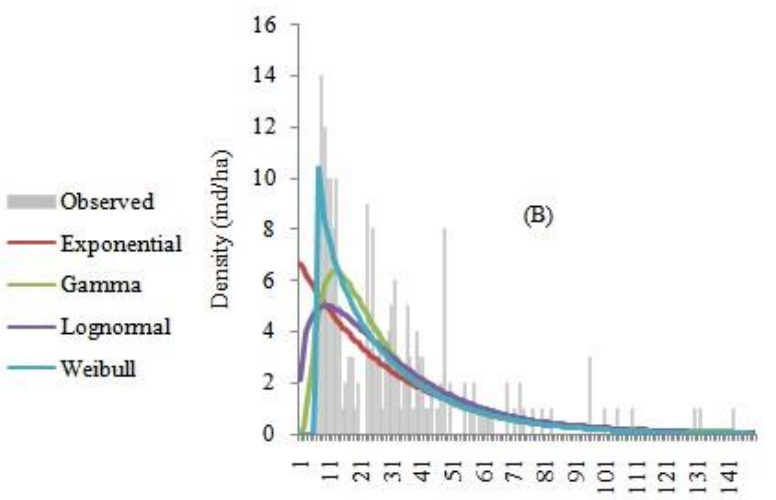

$\mathrm{DBH}(\mathrm{cm})$

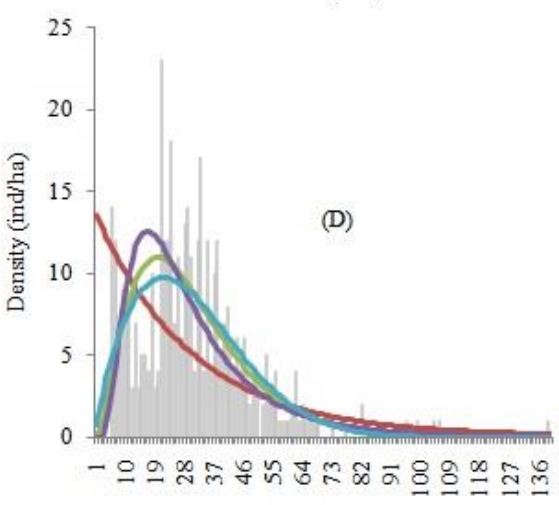

$\mathrm{DBH}(\mathrm{cm})$

Figure 4. Distribution family models for all species on (a) Binafun; (b) Bonmuti; (c) Letkole and (d) Oelbanu 
According to Sghaier et al., (2016), different types of parametric density functions have been used to describe tree diameter distribution in forest stands, including the Normal (Nanang 1998), Lognormal (Bliss \& Reinker 1964, Nanang 1998), Gamma (Nelson 1964), Beta (Clutter \& Bennett 1965, Palahi et al. 2007), Johnson's SB (Hafley \& Schreuder 1977, Palahi et al. 2007, Fonseca et al. 2009) and the Weibull distribution (Bailey \& Dell 1973, Palahi et al. 2007). According to the points mentioned, it seems that accessing a suitable model in a forest would be different noticing its site characteristics and conditions. So it has to be admitted that the results obtained here are influenced by this study's available data, and in other studies different results might be obtained (Fallahchai and Shokri, 2014). Differences in type of forests, species and condition topographic are the reasons of difference in the results (Mataji et al. 1999). These comparisons indicate that ecologic characteristics of a forest must be in especial consideration to obtain a suitable model.

\section{CONCLUSIONS}

Finally, it is worth mentioning that the results of this study are influenced by its data and it is likely that similar studies in different regions give different results (Mirzaei et al, 2016). Variety of dryforest conditions indicates differences on specific structure, composition of species and stand density. Diameter distribution model plays an importance roles in the dryforest management, especially on yield regulation. It can provide quantitative tools for a specific dryforests of East Nusa Tenggara, Indonesia.

\section{REFERENCES}

Bahnemiry, A.K., Abkenar, K.T., Pourbabaei, H. and Mirzaie M .2013. Modeling the Distribution of the Height of Chestnut Trees in the Forests of Gilan. International Journal of Science and Research (IJSR), Vol 4,5: 1095-1099.

BalitKlimat. 2004. Atlas sumberdaya iklim pertanian Indonesia. Departemen Pertanian. Indonesia.

Boreel, A. 2009. Struktur tegakan dan sebaran spasial jenis pohon torem (Manilkara kanosiensis H.J. Lam \& B.J.D. Meeuse) di pula Yamdena Kabupaten Maluku Tenggara Barat. Thesis. Institut Pertanian Bogor. Bogor.

Burkhart, H.E. and Tome', M. 2012. Modeling forest trees and stands. Springer, New York. 459 p.

Cao, Q.V. and McCarty, S.M. 2006. New Methods for Estimating Parameters of Weibull Functions to Characterize Future Diameter Distributions in Forest Stands. Proceedings of the 13th Biennial Southern Silvicultural Research Conference.USDA Forest Service Southern Research Station Asheville, North Carolina

Coomes, D.A. and Allen, R.B. 2007. Mortality and tree-size distributions in natural mixed-age forests. J. Ecol. 95:27-40.

Fallahchai, M.M. and Shokri, S. 2014. The application of statistical distributions to fit the diameter and height of a species of broad leaf in Hirkanian forests. Biological Forum - An International Journal 6(2): 82-85.

Huang, W., Pohjonen, V., Johasson, S., Nashanda, M., Katigula, M.I.L. and Luukkanen, O. 2003. Species diversity, forest structure and species composition in Tanzanian tropical forests. Forest Ecology and Management 173:111-124.

Knight, D.H. 1975. A phytosociological analysis of speciesrich tropical forest on Barro Colorado Island, Panama. Ecol. Monogr. 45:259-284.

Khongor, T., Lin, C. and Tsogt, Z. 2011. Diameter Structure Analysis of Forest Stand and Selection of Suitable Model. Mongolian Journal of Biological Sciences. Vol. 9(1-2): 19-22.

Cecep, K. 1997. Pengenalan Jenis Pohon Mangrove di Teluk Bintuni,Irian Jaya. IPB Press. Bogor.

Mataji, A., Hojjati, M. and Namiranian, M. 1999. Study on number distribution in diameter classes in natural forest by using probability distribution. Iran $\mathrm{J}$ Nat Resour 53(2):165-171.

Mirzaei, M., Aziz, J., Mahdavi, A. and Rad, A.M. 2016. Modeling frequency distributions of tree height, diameter and crown area by six probability functions for open forests of Quercus persica in Iran. J. For. Res. 27(4):901-906.

Mulyani, A., Priyono, A. and Agus, F. 2013. Semiarid soils of Eastern Indonesia: Soil classification and land uses. Developments in soil classification, land use planning and policy implications: Innovative thinking of soil inventory for land use planning and management of land resources. Innovative Thinking of Soil Inventory for Land Use Planning and Management of Land Resources. Springer Dordrecht Heidelberg. New York. London.

Ozcelik, R. 2009. Tree species diversity of natural mixed stands in eastern Black sea and western Mediterranean region of Turkey. Journal of Environmental Biology 30:761-766.

Padalia, H., Chauhan, N., Porwal, M,C. and Roy, P.S. 2004. Phytosociological observations on tree species diversity of Andaman Islands, India. Current Science 87:799-806.

Sghaier, T., Cañellas, I., Calama, R. and Sánchez-González, M. 2016. Modelling diameter distribution of Tetraclinis articulata in Tunisia using normal and Weibull distributions with parameters depending on stand variables. iForest 9: 702-709. - doi: 10.3832/ifor1688-008.

Simon, H. 2007. Metode inventore hutan. Pustaka pelajar. Yogyakarta.

Soerianegara, I. and Indrawan, A. 1988. Ekologi Hutan. Fakultas Kehutanan Institut Pertanian Bogor. Bogor.

Thomas, N.L. and Cao, Q.V. 2006. A Diameter Distribution model for Even-aged Beech in Denmark, Forest Ecology and Management. 231: 218-225.

Yam, G. and Tripathi, O.P. 2016. Tree diversity and community characteristics in Talle Wildlife Sanctuary, Arunachal Pradesh, Eastern Himalaya, India. Journal of Asia-Pacific Biodiversity 9 : 160-165. 